\title{
Prospects for Fundy tidal power
}

\author{
par R, H. Clark M.Eng., P.Eng.
}

\begin{abstract}
: Consultant in Tidal-electric Enginecring, Ajax, Ontario, Canada. He chaired the federal-provincial committees directing the preliminary Fundy investigations of $1966-69$ and $1975-77$ and acted ex advisor to the 1982 Update studies. He also chaired the Board of Review of the preliminary assessment of the Cook Inlet (Alaska) tidal power potential.
\end{abstract}

The Bay of Fundy area in Canada is one of the few places in the world where tides ranging up to 16 metres occur: Because of the magnitucie of this tidal variation and the configuration of the surrounding terrain, the area offers excellent possibilities for the construction of tidal-electric plants to exploit this energy. Figure 1 indicates some of the sites within Canada which have been subjected to various degrees of intersive study over the past half-century.

Although interest in exploiting the energy of the Fundy tides had been expressed early in the century, it wasn't until 1944 that the Governments of Canada and the Province of New Brunswick sponsored an investigation into the exploitation of the tidal energy th the upper end of Shepody Bay That study indicated that an hydraulically-linked, doublebasin scheme, incorporating the estuaries of the Memramcook and Petitcodiac rivers could produce about $1.3 \mathrm{TWh}$ annuatly but concluded the project was not economically justified. A number of investigations of limited scope were undertaken in the latc 1950's and early 1960's in the Chignecto Bay and Minas Basin areas but none of these was sufficiently delinitive to cstablish the merits of developmen.

Subsequently, comprehensive investigations undertaken during 1966-69, 1976-77, 1981-82 and 1984-85 have:

(i) provided an in-depth background to the potential for tidal power development in the Bay of Fundy;

(ii) identified the mont appropriate sites for development;

(iii) defined technically sound designs and construction methods; (iv) showed that a tidal power development will provide net economic benefits. These in-depth studies and the cumulative operating experience and record of the two modern, tidal power stations, the one at La Rance and the other at Annapolis, have demonstrated that, not only are there now avaitable proven and mature technologies for the exploitation of the energy of the Fundy tides, but also that such exploitation can be competitive to conventional sources of electical energy in the Maritime provinces. However, notwithstanding the positive results that have been obtained from these preliminary, feasibility and update studies, very litlle, if any, progress has subsequently been made towards realizing a tidal power project in the upper reaches of the Bay of Fundy. Some research activities relating to environmental and ecological aspects have been undertaken under government sponsorship since 1977, such as the development of a hydrodytamic model which will be useful in predicting: for example, changes in sediment regime, but such research has been sporadic and uncoordinated.

\section{E RESULTS OF RECENT INVESTIGATIONS}

To set the stage for a decision on the next phase in the exploitation of the renewable energy source in the Fundy tides, the major conclusions and recommendations of the previous studies are reviewed and examined.

\subsection{6-1969 Investigation}

The Atlantic Tidal Power Programming Board (ATPPB)

\section{Perspectives de lénergie marémotrice dans la baie de Fundy}

La baie de Fundy ai Canada possède probablement les conditons les plis fruorables dans le monde de l evploita tion de l'énergie narénotrice Les résultats des investigations conduates durant le dennier quart de siècle sont décrits y compris les aspects d'exploitation et d'impact sur l'enivoniement pour la centrale d'Annapolis (20 MW) mise en service en 1984 Au dépant, cetté dernère était destinée an test des unités de turbines à grand dianère (7,6 m) STRAFLO sur des petits hateurs de chute.

Les études montrent que le developpement d'ute centrale de $1400 \mathrm{MW}$ en tête de la baie de Fundy est techniquenient et écononiquement viable et qu'tue telle centrale pourat êtreconpétitive avec des centrales à conbustibles fossiles. L'impoitance di réglage est discutée dans le cas où l'exploitation de cette source d'énergie renouvelable et non polluante coirespondrait aux besoins des provinces marifimes. 
was established by agreement of the Governments of Cantala, New Brtnswick and Nova Scotia. The Board concluded that economic development of tided power was not feasible under the then prevailing circumstances. However, it recommended that additional detaited studies be atthorized in the cvent of significant changes in intercst rate, construction costs, conventional energy prices, or threatened exhaustion of conventional supplies. Significant changes dit octu is both energy prices und supply position within three years of the submission of the Programming Boarci's report on 31 October 196911 :

In the light of those changes, the Federal and the wo Maritime provincial governments established, on 29 February 1972, the Baly of Fundy Tidal Power Review Board. After reviewing and updating ATPPB estimates of the cose of tidal power development examining certat marketing possibilities and comparing market value of tidal power with the value of energy from fossil fuels, the Board concluded that the relative economic merits had converged sufficiently to wartant undertaking more comprehensive surdies on a phased basis. In this way, the investigation could be terminated if the results of any phase indicated that tidal power could not becone competitive with atternative energy sources.

In submitting its conclusions to governments, the Board pointed out that there are incentives which might encourage the market area to purchase tidal energy because reductions in fossil-fired energy production would result in : (i) reciuced atmospheric and watter poltution; (ii) reductions in demand on finite oil and gas reserves, wirich could be diverted to more critical purposes. Nso, the necessary transmission facilities dedicated to a tidal power project would undoubledly provide opportunitics for transmission of power between power systems in eastern Canada. In addition, it is intercsting to note that, at that time, the Review Board also expressed its opinion that nuclear, not fossil fuel, power costs will constitute the long-term yardstick for economic evalustion of energy projects.

\subsection{5-1977 Reassessment Studies}

The three governments, acting upon the Board's conclusions agreed to tinance further investigations and directed the Board on December 3, 1975 to cany out further studies with the object of providing a firm estimate of the cost of tidal cnergy in relation to its alternatives, on which to base a decision to proceed further with detaled investigations and enginearing design. On December 2, 1977, the Review Board reported [2] that the reassessment had conclusively demonstrated the fundamental economic feasibility of tidal power and the technical and economic feasibility of its integration into the projected gencration supply systems of the Maritime Provinces and recommended, inter alia, that funding be provided to complete detailed engineering, socioeconomic and environmental investigations and financial planning for the development of at tidal power project at the mouth of Cumbertand Basin, i.e. Site A8. Lirfortunately, these recommendations were not acted upon at that time

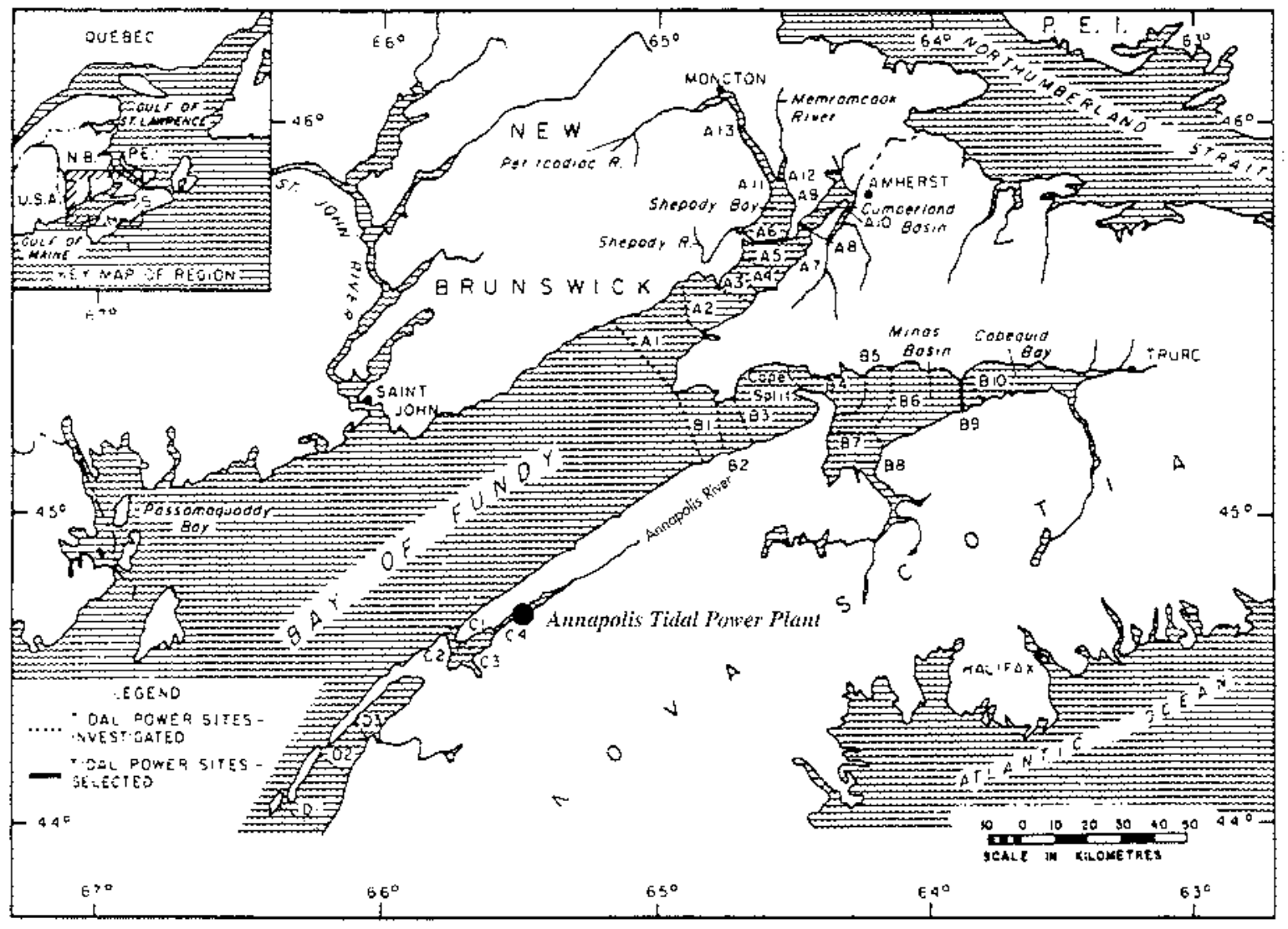

1. The Bay of Fundy. 


\subsection{Update ' 82}

With major lunding provided by the former federat Department of Energy, Mines and Resources, the Tidal Power Corporation of the Prevince of Nova Scotia undertook a revision of those portions of the Review Buard's work rendered out of date by changes in cost, technology, policies of outlook subsequent to 1977 which the Review Board, at its lest meeting, had recommended be undertaken. The Update Task Force [3], set up by the Tidal Power Corporation to carry out this review concluded, inter alia, that significant reductions in overall cost could be achicved by shortening the construction period which should be one of the objectives of defmitive design. The Task Force also noted that, under a reasonable marketing strategy, which would involve allocating a considerable portion of output to export markets, a tidal power development would be cconomically viable with a benefit to cost ratio in the 2.4 to 3.0 range. The Task Force also noted that the work done to that time fell far short of providing all the information required to launch a tidal power project and that a pre-commitment programme encompassing definitive designs and socio-economic and environmentat assessments should be undocrtaken.

\section{a 1.4 1984-1985 Feasibility Lpdate}

Subsequenty, the Federal and Nova Scotia govermments agreed to finance a studly by a private sector interest, the Aluminium Company of Canada (ALCAN), which would be aimed at determining more closely the technical and economic aspects of Site $A 8$, at the entrance of Cumberland Basin between Nova Scotia and New Brunswick (Figure 1). Based on a review of the activities, results and conclusions of ALCAN's study, the Nova Scotia Trdul Power Corporation concluded [4! that funther technical work aimed at reducing development costs could be accorded a relatively low priority. It also concluded that the launching of a Stage 2, precommitment programme, should await further resolution of the marketing, retiming and transmission questions. However, it was emphasized that if means of re-timing the output of Sitc $A 8$ could be established, Stage 2 studies should be undertaken promptly and a high priority given to establishing feasibtily conditions for the development of that site. In this connection, further studies are required to examine how Compressed Air Encrgy Storage (CAES) Systems and/or the hydro storage of interconnected systems can be integrated with tidal power to provide a high guality source of generation for electrical systems.

\section{約 1.5 Summary}

The updates of 1982 and 1985 proved useful in that they reflected, in updated costs, the current knowledge of turbinc/generator performance and improved construction techmigues. Curently, the Sitc A8 design would consist of 42 single-effect turbines with a rating of 34 MW for an installed capacity of $1,428 \mathrm{MW}$ giving an annual energy (net of transmission loss) of $3,307 \mathrm{GWh}$.

\section{If IHE ANNAPOLIS TIDAL GENERATING STATION}

In the late 1970 's, it was considered that larger scale development of the straight-flow turbine, als developed by Escher Wyss for its STRAFLO unit, could improve the economics of harnessing undeveloped hydro resoureses in Canada and enhance prospects for development of major tidal energy sites in the Bay of Fundy. Scveral units of this design, which featured improved seals between rotor and the water passage structure, had been instalted in Furope but they were far smaller than the optimat sizes for Canadian sites, then under consideration.

Interest in a low-head demonstration project was shared by various utilities across Canada as well as by the Government of Canada and by tidal power investigators. Largerscalc development of at new hydro-electric turbine could improve the prospects for development of major, tidal cnergy sites in the Bay of Fundy. A causeway which had been constructed across the mouth of the Annapolis River in 1963 was selected for the site since it would minimize the capital oullay as well as ofler experience in commercial operation at least cost. The causeway had been constructed to provide better drainage and protection for the dyked lands around the Annepolis Basin and to carry a roadway to replace an old bridge. The cansicway was already equipped with a fistoway and with sluices containing vertical lift gates. The sluices would be closed against the llood tide when the Annapolis River itself was in flood so as to limit the water level in the head pond to $1.8 \mathrm{~m}$ above the mean sea level.

A commitment decision was made on 5 December 1979 when the Govemments of Canada and Nova Scotia annouryced an agrement to construct a low-head hydro demonstration plant at Annapolis, With a $\$ 25$ million grant by the Federal Government, the former Xova Scotia Tidal Power Corporation, as owner of the plant, undertook to fund the berlance of the cost and engaged Nova Scotia Power 10 design, construct and operate the project. Design was based on single-effect, ebb generation using one single-regulated STRAFLO unit of $7.6 \mathrm{~m}$ throat diameter - the same size as planned for large tidal power plants in the Bay of Fundy.

\subsection{Review of Plant Operation}

Construetion commenced in 1980 and the plant entered commercial service in August 1984. The Annapolis Tidal Generating Station has been described in detail in papers by Delory [5] and by Rice and Baker [6] Much was learned during construction and commissioning of Annapolis Tidal Power Plant, but forg service is required to assess such things as longevity, resistance to corrosion and maintenance needs. Comments on the performance, maintenance and enviromental aspects are presented hereunder.

\subsection{Performance}

The unit attained specilied outputs at the specificd heads, i.c. $17.8 \mathrm{MW}$ at $5 \mathrm{~m}$ and $19.9 \mathrm{MW}$ (overloat with 2-hour rating) at $5.6 \mathrm{~m}$. Rur-up and synchronization are attomated and the facilities proved adequate to surmount difficuties imposed by the large inertia of the rumer and the tendency for wicket-gate operation to cause seiches in the headpond.

Anmul output has been in the range of 30 GWh per yew which is well below the planned target of $50 \mathrm{GWh}$. This has been due, in part, to changes made during construction of the project and shortly thereafter. Hard strata in the discharge channel had escaped detection in preliminary dritling and, when discovered, it was decided to accept a shatlower channel. This resulted in a small increase in the taitrace elcvation. However, a larger refuction of available head resulted from a decision during the first year of operation to timit the maximum headpond level to $6 \mathrm{~m}$ above mear sea level. The out-ol-phase discharge may also teduce 
the tidal range at the site but the gauging necessary to check this possibility has not been undertaken.

Two start-up troubles were encountered. One resulted from the fact that the field coils of the rim generator had not been sufficiently insulated by the manufacturer who was concerned with heat dissipation and did not encapsulate them as specified. This problem was resolved by applying an epoxy coating. The insulation resistance is still low but outages are avoided by keeping the windings wam when the unit is not running. The other problem arose from the fact that the plant uses sea water for, among other things, cooling the generator through heat exchangers, cowling the bearing oil and lubrication of rim seals. The clearance between the latter und the metal face of the stationary metal is very small, so the intake water is filtered. The filters tend 10 plug very quickly and back-washing was not eflective. $\Lambda$ different type of filter with continuous backwash solved this problem.

For a tidal plant, it is reasonable to definc availubility as the ratio of operating time to the tolat time when head equals or exceeds the minimum operating head. On this basis, the Annapolis unit has consistently achieved an availability of about $99 \%$. Typical availability of hydro units operated by Canadian utilities is in the $95-96 \%$ range.

\subsection{Maintenance}

The wetted surfaces of the intake, the turbine unit and the draft tube have active cathodic protection. With the exception of a spot at the root of one muner blade, this has completely inhibited corrosion. The runner blades are stainless steel and the hub is carbor steel. In its manufacture, five layers of gradually changing composition were welded between the hub and runner to avoid creating undesirable potential at the joint. It is possible that there was some irregularity at the point now subject to corrosion. The affected arca is only a few square centimetres and repairs are made every few years when the machine is dewatered for other purposes.

The water passage has remained free of marine fouling communitics possibly due to the applied potentials or perhaps, although less likely, duc to high water velocity. Therc is a heavy build-up of mussels upstream of the stoplog gains at the intake, but the gains and the areas downstream thereof are clean. The contrast is striking.

After about three years in service, a decreasing trend in the flow of sealing water was noted. By the following year, the flow had dwindled to the point that remedial action was necessary, The unit was dewatered and the seals removed. It was found that the small water passages which delivered high pressure water to the race of the seals had become choked by deposits of manganese. The deposits were removed by scraping and the unit returned to service. In was determined that the deposition of manganese, normaily present in sea water, was being triggered by the small amounts of chlorine, used to inhibit marine fouling, in the water taken in for plant operating purposes. Since it was judged unwise to disperse with this protcction, the seals are removed and cleaned at intervals of threc to four years. No sign of seal wear has yet been detected. This latter problem could have been avoided by using fresh water for plant tuse instead of the readily available salt water. Although water utijity mains run past the plant, the demonstration was designed to uncover the problcms cutailed in the use of similar machines for large tidet plants where tresh water would not be so conveniently available as well as those in river hydro applicutions.

Avoidance of corrosion on metal surfaces exposed to air in the turbine pit requires some maintenunce effort. The external surfaces of water passages are chilled by sea water so that atmospheric water vapour tends to condense on them, particulariy during the intervals between operating periogs when there is no stray heat from the generator, and the atmosphere tends to have some salt content as is usual in proximity to the sea. Heat and ventilation are provided but there is no air conditioning. Costs and benerts of including this feature in future tidal plants of this type may jeserve cateful analysis.

There has been no indication of wear in upstream and downstream fotor bearings. There are no trash racks so that the runner blades are relicd upon to deat with any trash or ice and have proved capable of doing so. However, a wickes gate operating link was bent on one accasion when some timbers of $30 \times 30 \mathrm{~cm}$ cross-section passed through the mactine.

In summary, mintenance requirements have been met by taking the unit out of service for about two weeks every three or four ycars. This is less than had been expected and significantly less that the allowance used in feasibility studies for large tidal plants at the Fundy sites.

\subsection{Environmental aspects}

The environmental requirements for the project were supervised by an intergoverumental environmental advisory committee (IGEAC). It was the frrst instance of unjfed environmental control and saved the project from the confusion and delays entailed in meeting the requirements of a number of independent agencies. Over 30 studies were carried out dealing with various real or conjectured impacts. The main potential impacts identified by these studics involved either the marine ervironment or the low-lying farm lands adjacent to the head pond. Potential marine impacts comprised delays imposed on migrating anadromous fish, fish mortality and siltation. Potential tertestrial impacts comprised salt intrusion, impaiment of drainage, flooding, erosion and salination of headpond surface water used as water supply for livestock.

A section of the sluiceway, built when the causeway was constucted across the estuary some years earlier, is left open at all times to provide fish passage. The IGEAC considered that it was not close enough to the turbine and ordered construction of a second fishway immediately adjacent to the intakc. limits were also defined for the relcasc of sediment during construction and these were not exceeded. In the headpond arca, aboiteaux were constructed in the drainage oullets of low-lying dyked lands and water supply from small streams was provided where needed. Provision was mate in the station operating logic for strategies that would avoid exceeding the target maximum headpond level, based on tidal and river flow data.

During the construction and commissioning periods there was a good deal of concern about impacts. This concen reached a crescendo when operations commonced and the headpond clevation was gradually being changed to its intended Final level. The concern was fanned by the media and, since it was new and clearly visible, the plant was blamed for any real effects that had existed for decades as well as for imagined new impacts. The enviromental authorities received many conplaints. One such complaint concerned a yellow 
dust observed on water surfaces in the area which tumed out to be polten from spruce trees which has fallen on Nova Scotia in the month of May since time immemorial.

The plant was also blamed for the disappearance of crams on one tidal flat about 5 miles westwato of the plant and clam fishemen demanded closure of the plant. Investigation showed that the immediate causes were the failure of new clam spat to sette on the flat coupled with the effects of a predatory marine worm. Before the investigation was completed, an new gentertion of clam spats setled and the fiat was repopulated. Obviously, this event hat nothing to do with the plart which was operating throughou this whole period.

Now, aiter more than 12 years of operation, the real impacts can, in most cases, be assumed to have become readily ouservable so that it is posibib to moke a fairly reliable assessment. The following summary is based on published and unpublished research as well as the presence or absence of techrical or public concern.

\subsubsection{Fishery Intpacts}

Fish species frequenting the river include Atlantic sulmon, striped bass, shad and olue buck hering. Among these, shad have beer used from the outset as the marker species because of their numbers and the associated sport lishery.

A 1995 survey of the sind population found that the indjo vidual fish size, age and estimated number of spawning fish were somewhat lower than in 1985. This would be consistent with moderate turbine mortality but it could also be part of the general malaise which has affected most species of commercial importance in the Attantic fishery. In any case, the population is still large and it is reasonable to conclude that any effects due to the plant had stabilized by that time.

There is a fall salmon run but is is not fished. Many years before the tidal plant was built, salmon were adversely aifected by river hydro developments. The local, striped bass fishery has varied over the years with the success or failure of each year class. Data are nol available but the fishery still exists. The productivity of the headpond, whick supports juvenile anadromous fish, has improved since the plant went into operation and cxhibits more biological diversily.

Efforts made to develop bchavioral means of diverting fish from the vicinity of the turoine to the original fushpass met witir only limited success. In the course of this ctront it was found that about wo-thirds of the adult fist making a downstream passage use the sluice rather than the turbine.

In summary, the impacts on important fish species have, at worst, been only moderate and do not threaten the demise of fish stocks.

\subsubsection{Scdimentation}

Single-effect ebb-generation imposes conditions more favourable to deposition of sediments in the headpond than the prior regime uider which at least two of the threc siuice gates were normally open throughout the tidal cycle. The rate of sedimentation has, in fact, increased in the lower reaches of the headpond. This implies that in the absence of any increase in the rate of upstream erosion and the concentration of suspended solids, the discharge through the barrage must carry less sediment than under prior conditions.

\subsubsection{Erosion}

The rate of erosion in the estuarial scction of the river between Antapolis Royal and Bridgetown increased when the causeway was built in the early 1960 's. This is attributable to decreased salinity in the headpond and a corresponding decrease in the energy required to cause scouring. It was conjectured that plunt operation would increase salinity and, if unything, reduce erosion. Transects of the shoreline taken after about three yeurs of operation were compared with similar data taken before start-up. The comparison tended to show that there nad been some stumping but that there had been little overalt loss of material. However, erosion does not proceed in those soils at a stealy rate and the results were not regarded as conclusive. The author is not aware that any more recent data exist.

\subsubsection{Protection of Agricultural Soils}

Extensive piezometer measurements taken before and after start-up in the most sensitive arees of the dyscland surrounding the headpond failed to record any indication of saline penetration as a result of the new headpond regime. The soils have extremely low permeability and surface runoff is the usual form of drainage, although some 'mole' drainage is atso used. The aboiterux which had been irstalled as part of the remedial programme, function is intended so that the pre-existing drainage conditions are unaleced.

The plant operating logic provides computerized control of headpond levels and controls the surface clevation with an error of not morc than about $5 \mathrm{~cm}$. The turbine is available to augment discharge capacity, if necessary, in the event of floods. Level control before the plant was buit was based on human judgment and exercised through manual control of sluice gates. At times, the heacpond rose nearly 3 m above the intended level.

In summary, the plant has increased the accuracy of control and has cnhanced the quality of dykeland protection.

\section{III $\square$ PROSPECTS FOR DEVELOPMENT}

The foregoing brief review of conclusions/recommendations and comments from the investigations/reassessments/updates which constiutc the feasibility or Phase 1 study of a potential project, and tite cxperience gained in the operation of the Annapolis Tidal Power Plant with its large diameter STRAFLO turbine, make it abundantly clear that a tidal power development at Site AB is technically and economically feasible. Moreover, contemporancous discussions also reveal that, more than likely, its output would be competitive with that of fossilfired plants, particularly if a 'green' accounting technique, i.c. putting a dollar value on all environmental costs, were applied to all electrical energy sources. Therefore, it secms obvious that there is sufficien information on which to base an authorization for the necessary pre-investment activitics that would lead to a definitive proposal, i.c. definnitive designs and specifteations for development of Site A8 (Phase 2), which would be a pre-requisite for a comprehensive envirommental impact assessment'.

There is a great deal of work to be carried out during a Phase 2 investigation before any decision could be made to construct. For Site A8, some of the required dati and activities are :

(i) additional seismic proffles as well as four to six bore holes to investigate overburden and rock;

(ii) additional basic data on sedimentation and ice conditions; 
(iii) refinement of the closure method to relate it to construction staging and schedule and lunar tidal cycles;

(iv) additional wave climate data and stom surge modelling is required as well as more detailed generation-supply and generetion planning stuöics, etc;

(v) some hydraulic model studies will have to be undertiken since there are several areas/problems for which only physical models would be capable of adequately simulating the physical plrenomena to produce the required information with sulficient accuracy .... such models would also be of assistance to the construction and eventual operation of the various structures, should a construction decision be made. Alhough some isolated environmental studies have been undertaken by research agencies, more comprehensive, intensive and coordinated environnental investigations ase required, based on a definitive design. The foregoing are orly a few of the essential activitics encompasser by a Phase 2 - Pre-investment Design Program.

In view of the capital-intensive nature of tidal-electric, hydroelectric and nuclear projects, a primary concen is project financing. Since a high, real interest-rate environmen distorts the perception of the long-term value of the project, the 1984-85 study suggested that this difficulty could be resolved if project financing could be arranged at an indexlinked interest rate consisting of a real component of approximately four per cent plus an inflation component equal to the curent year's inflation rate. At the present time, the Bank of Canada rates are at a four-decade low of less than 3.5 per cers.

Tidal power would seen to have a unique feature which hasn't yet been explicitly acknowledged. There seems to be a consensus (at least since the 1973 world oil embargo) that the project would have been cconomic if embarked upon on earlier occasions but never on the current one. This characteristic was intimated during the preparation of the preliminary reassessment report of September 1974 and it was also expressed in the Jamuary 1987 issue of International Power Generation under the heading "Tidal power; is it all a que:tion of timing?».

Timing is of the utmost importance. A Phase 2 programme would require about 3 years to complete and, if its conclusions were positive, the construction of an $\wedge 8$ project would take an additional 6 to 8 years. Thus, there would be a period of 10 to 12 ycars, at least, before a plant at $\mathrm{A} 8$ could be fully operational. Even though the installed greneration capacity of the Maritime Provinces is sufficient until after the turn of the century, when capacity additions will become necessary, the development of A8 could not be undertaken unless the necessary investigations and environmental studies were initiated in the very near future.

In the 1988 publication, Into the Mainstream: Strategies for a Secture Enviromment, issued under the authority of the Minister of Fnvironment Canada, it is clearly stated that :

"For the first time in the history of this planet, people have the capacity to significantly affect and alter the global envirmment. Acid rain, accidents involving nuclear energ;; or the release of chenticals can threaten air, land and water halfway around the world. Consumption and production practices which are seemingly insignificant at the individual level are now understood to have profolnd inmediate, Iongterm and camulative hamful effects on the health of our planet. Massive deforestation, buming of fossil fisets, and use of certain chemicals in ordinary household products are leading to potential long-term global changex."

"The true costs of some resources may need to be brought onto the conventional balance sheet."

The true cost of energy from fossil-fuelled power plants is not revealed when comparing energy sources for electric power gencration, such as price supports/constraints or the 'real' costs of large oil spills which are not reflected in the cost of fuel for power plants, nor are the costs arising from the destructive effects of acid rain. Nuclear energy costs do not include the 'real' costs of decommissioning a nuclear power station or the costs of disposal of its waste products. How are the costs of nuclear 'accidents' or of massive oil spills to be factored into the costs of energy from these energy sources ? It must be kept in mind that all forms of electrical energy production have some environmental effects. The advantuges of renewable energy sources muse be recognised, particularly with respect to greenhouse effects, diversity of supply and fuel price increases[7].

It is often argued that conventional power plants have fewer uncertainties because of the extensive experience which is readily available but this is not necessarily so. For example, although nuclear power has reacled a state of maturity, there was a serious incident at Three-Mile Island in 1979. Tidal plants do not pose an extraordinary risk. Tradeoffs have to be confronted and decisions mate in everything that is done and constructed with resulting disadvantages and advantages to society.

There are few important disadvantages in exploiting tidal energy. Paramount, of course, is the effect on fish, fowl and wildiffe. Such effects resulting from the operation of the La Rance and Annapolis plants are now fairly well known and it would appear that the disadvantages can be overcome or are outweighed by the many advantages of tidal energy [8] :

A large tidal power development in the Canadian Bay of Fundy could have an international aspect since its location and operation would affect the resonance of the Bay and the Gulf of Maine. Hydrodynamic numerical modelling predicts that a barrage at Site A8 would change the natural pertod of the Bay/Gulf system so as to increase tidal anplitudes. The change in tidal range at Boston would be about $3 \mathrm{~cm}$ as a result of the operation of a plant at Site A8. The lower Bay and Gulf would experience increased currents. More nutrient-rich water from below the ocean thernocline would be brought in and fish spawning and larval distribution wonld be affected. Cold water species, which form the majority of the fishery, would benelit. In view of the foregoing international, envirommental effects, there would be an obligation to give Lnited States authorities a voice in environmental regulation and control, particularly if output from the tidal plant were to be exported to the Lnited States.

Tidal power developnent must be a multi-government effort in view of the far-reaching environmental considerations and the signiticant regional socio-economic benefits as well as the frnancing of the project. The current uninterested or wavering attitude of governments to this economic, nonpolluting electrical energy source, resembles the 'French Wavering' described by Dr. Robert Gibrat [9]

The next step will involve the preparation of a development or framework plan for the pre-investment investigations of Phase 2, including a critical path analysis to identify those items which are sensitive to time constraints in logistics planning, and which would provide the definitive designs and specifications, inteluding the environmental impact 
assessment, for a tidal power development at Site A8, that is, the requirements necessary for a clear and infomed decision to construct or forget the project.

\section{Acknowledgement}

The author is indebted to Dr. G. C. Baker for the text summarizing the operation and effects of the Annapolis Tidal Power Plant.

\section{References}

[1] Feasibility of Tidal Power Development in the Bay of Findy. Board Report and Commitec Report, Atlantic Tidal Power programming Board, Department of Energy, Mines and Resources, Otawa, 1969.

[2] Reassessment of Fundy Tidat Power. Bay of Fundy Tidal Power review Board and Management Committee, Department of Energy, Mines and Resources, Otawa, 1977.

13: Fundy: Tidal Power, Update '82. Tidal Power Corporation, Halifax, Nova Scotia, 1982.

41] Furdy Tidal Power; Stage 1. Repont of Tidal Power Corporation, December 1985
15) Delory, R.P., The Annapolis Tidal Generating Station. Symposium on Water for Energy sponsored by BHRA, Brighton, England, 14-16 May, 1986.

[6] Rice, R.G. and G.C. Baker, Amapolis: The STRAFLO Thrbine and Other Operating Experiences. Proc. Sym. posium on Tidal Power, Institution of Civil Engineers, London, March 1992.

[7] Mutrhead, Dr. S.J., The Environmental Effects of Tulal Energy. Proc.Symposium on Tidal Power, Institution of Civil Engineers, London, 1992.

[8] Cambel. A.B., Tidal Power, Its Promises and Problens. In Energy Sotrces : The Pronises and Problems. Center for Industrial and Institutional Development, University of New Hampshire, Feb. 1980.

19: Gibrat, Dr. Robert, Tidal Pesser in 1980 . Pape: prepared for publication in the monthly review of the Professional Society of Former Students of the Polytechnical School.

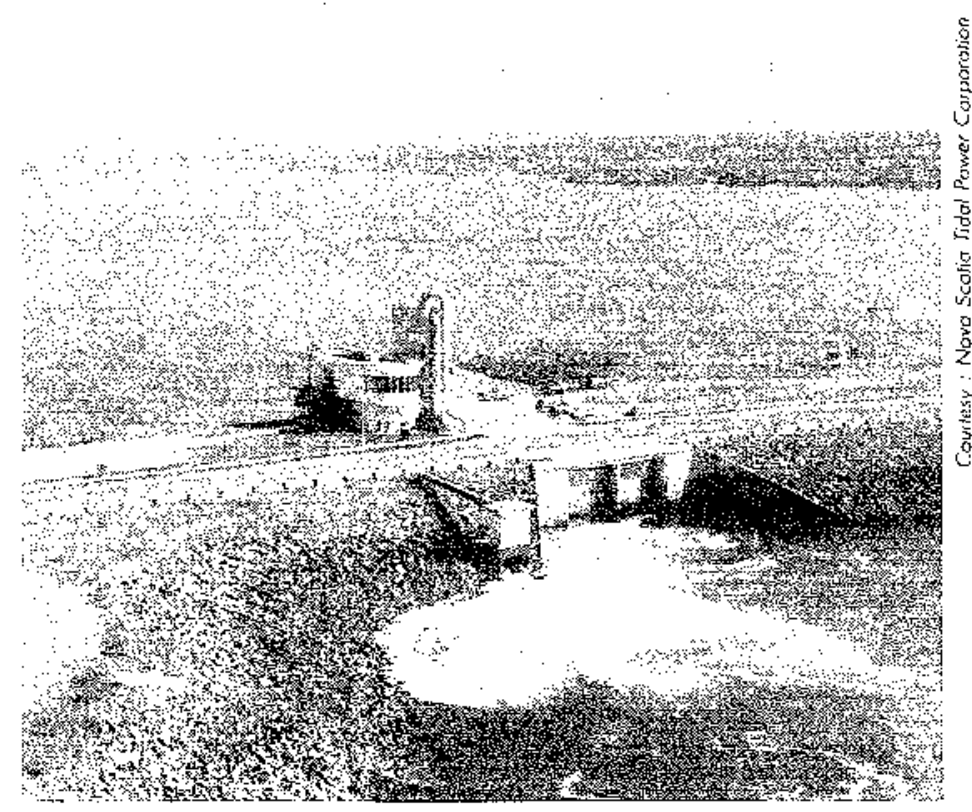

2. The Annapolis Tidal Power Plant. 